
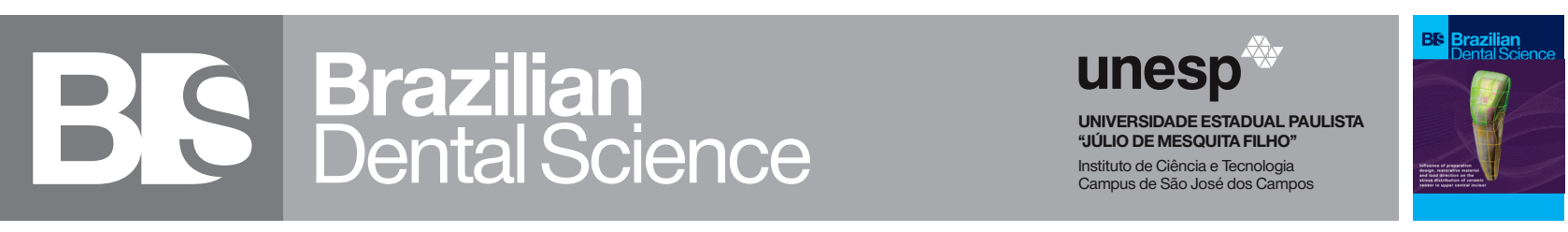

\title{
A one-year clinical evaluation of IPS E.max press versus CERASMART endocrowns in anterior endodontically treated teeth: a randomised clinical
}

Avaliação clínica de um ano de IPS E.max Press versus CERASMART endocrowns em dentes anteriores tratados endodonticamente: um ensaio clínico randomizado

\begin{abstract}
Norhan Naief Abd El HALIEM ${ }^{1}$, Jylan ELGUINDY', Amina A ZAKI ${ }^{3}$
1 - Faculty of Oral and Dental Medicine- Egyptian Russian University- Cairo- Egypt.

2 - Faculty of Dentistry- Cairo University and Vice Dean for Education and Students Affairs- Nahda university- Cairo- Egypt.

3 - Faculty of Dentistry- Cairo University and Head of the Fixed Prosthodontics Department - Faculty of Oral and Dental Medicine, Egyptian Russian University, Cairo- Egypt.
\end{abstract}

\section{ABSTRACT}

Objective: The purpose of this study was to evaluate and compare gross fracture, patient satisfaction and marginal adaptation of anterior endocrowns restoring endodontically treated anterior teeth fabricated from IPS e.max press and CERASMART hybrid ceramics. Material and Methods: A total of 24 patients were selected to receive an aesthetic endocrown for an upper tooth in the aesthetic zone (central incisor, lateral and canine).The 24 patients were divided into two groups $(\mathrm{n}=12$ each), where Group 1, the control group, received an IPS e.max press anterior endocrown and Group 2, theintervention group, received a CERASMART anterior endocrown. After cementation all patients were followed up at 3, 6, 9 and 12 months. During each followup examination, United States Public Health Servicecriteria were adopted for clinical evaluation to score margin integrity and gross fracture. Questionnaires were also used to evaluate the patients' satisfaction and potential postoperative discomfort. The $\mathrm{X}^{2}$ or Fisher's Exact test were used to compare qualitative variables in the two groups and Friedman's test was used to study the changes over time within each group. The significance level was set at $\mathrm{P} \leq 0.05$. Results: With regard to gross fracture and marginal integrity, there was no statistically significant difference at any

\section{RESUMO}

Objetivo: o objetivo deste estudo foi avaliar e comparar a fratura grosseira, a satisfação do paciente e a adaptação marginal de endocrowns em dentes anteriores tratados endodonticamente, fabricados a partir de IPS e.max press e cerâmicas híbridas CERASMART. Material e Métodos: Um total de 24 pacientes foi selecionado para receber endocrown em um dente superior na zona estética (incisivo central, lateral e canino). Os 24 pacientes foram divididos em dois grupos ( $\mathrm{n}=12$ cada), onde o Grupo 1, o grupo controle, recebeu uma endocrown anterior IPS e.max press e o Grupo 2, o grupo de intervenção, recebeu uma endocrown anterior CERASMART. Após a cimentação, todos os pacientes foram acompanhados em 3, 6, 9 e 12 meses. Durante cada exame de acompanhamento, os critérios do Serviço de Saúde Pública dos Estados Unidos foram adotados para avaliação clínica para pontuar integridade de margem e fratura grosseira. Questionários também foram usados para avaliar a satisfação dos pacientes e potencial desconforto pós-operatório. $\mathrm{O}$ teste $\mathrm{X}^{2}$ ou teste de Fisher foi usado para comparar as variáveis qualitativas nos dois grupos, e o teste de Friedman foi usado para estudar as mudanças ao longo do tempo dentro de cada grupo. O nível de significância foi estabelecido em $\mathrm{P} \leq 0,05$. Resultados: Com relação à fratura grosseira e integridade marginal, não houve diferença estatisticamente significativa em qualquer intervalo de tempo entre os endocrowns IPS e.max 
time interval between IPS e.max press and CERASMART endocrowns. All patients reported being satisfied with their restorations until the end of the follow-up period. Conclusions: CERASMART anterior endocrowns provided a promising treatment modality compared to IPS e.max press anterior endocrowns.

\section{KEYWORDS}

Anterior endocrown; Anterior endodontically treated tooth; Gross fracture; Marginal integrity; Patient satisfaction. press e CERASMART. Todos os pacientes relataram estar satisfeitos com suas restaurações até o final do período de acompanhamento. Conclusão: os endocrowns anteriores CERASMART proporcionaram uma modalidade de tratamento promissora em comparação com os endocrowns anteriores IPS e.max press.

\section{PALAVRAS-CHAVE}

Endocrown anterior; Dente anterior tratado endodonticamente; Fratura grosseira; Integridade marginal; Satisfação do paciente.

\section{INTRODUCTION}

7 ndodontic treatment causes the loss of a considerable amount of tooth structure due to the central destruction created by the access preparation, in addition to the existing trauma or caries. This usually leaves the tooth with an insufficiently sound structure, resulting in increased cuspal deflection during loading; this in turn increases the occurrence of crown fractures and microleakages at the margins. In such cases treatment should be designed to protect and strengthen the remaining amount of endotreated teeth. The material and prosthetic treatment choices thus play an important role in the longevity of such restorations[1-4].

There are a number of different treatment modalities for restoring Endodontically Treated Teeth (ETT): Direct restoration, a crowns retained using a post and core, amalcore, inlay and onlay, and anterior endocrowns. Endodontic posts and core are the classic approach for restoring endodontically treated teeth, as they have physical properties very similar to natural dentine. Before the introduction of adhesion technology in dentistry, the coronal restoration of ETT was most often performed using metallic and macro-mechanically retained posts. Castmetal posts and cores have a high elastic modulus compared to root dentin, creating a more rigid restorative complex which causes high stress concentrations in the root and leads to a high incidence of vertical root fractures [5-7].Ceramic, glass and zirconium posts have gained popularity because they are tooth-coloured and avoid aesthetic problems in the anterior teeth; however, the only way to remove non-metallic posts is to grind them out with a bur, which is a tedious and dangerous procedure. These posts should be avoided because they may make retreatment impossible even if it becomes necessary [8].

Stress analysis has shown that cast-metal posts and cores create high stress concentrations inside the root canal. Such high stress concentrations can initiate vertical fracture and micro gaps in the cement-dentin or cement-post interfaces, resulting in bacterial colonisation and periapical lesions. Preparation of the canal has also been shown to weaken the root and decrease its ability to withstand force[3].To avoid these problems and to increase patient's aesthetic expectations, post materials have been improved in many ways, including the use of high flexural strength and elastic modulus close to the dentine. A wide range of natural-tooth-coloured and metal-free post materials, such as fibre reinforced composite posts with mechanical characteristics similar to those of dental tissues, have also been developed [9].

Several studies $[10,11]$ have reported that the process of applying posts weakens the roots, 
in addition to the risk of perforation during the preparation of the post space. Today posts are no longer mandatory for restoring non-vital teeth unless there is evident insufficient core retention[12].A tooth with substantial coronal structure loss requires core build-up and a crown[13]. The purpose of the core restoration, with or without a post, is to replace lost dentine, provide internal support and retention for the crown, and ensure resistance against cervical tooth fracture. The presence of adequate tooth structure (ferrule) at the crown-root interface is critical for the long-term success of the crowned endodontically treated tooth[14]. A minimum sound dentine height of $1.5-2 \mathrm{~mm}$ is required between the core and crown margins. The final restoration provides a bracing, casing or hugging action to improve the integrity of the endodontically treated tooth. Optimal ferrule length transmits occlusal forces to the periodontiumin normal physiological fashion [15].

In modern conservative dentistry, the retention of restorations is based primarily on adhesion, so the use of macro-retentive elements is no longer required in every case. Over the last 30 years, the development of adhesive systems has led dentists to question the indications for crown restorations. Modern clinical procedures to restore ETT are instead based on the principles of minimally invasive dentistry, which attempts to conserve sound tissues without the need for aggressive macroretentive techniques[13].

In 1995 Pissis [16]introduced the heatpressed ceramic monoblock technique, which utilised the pulp chamber to increase the macromechanical retention of the crown. In 1999 Bindl and Mörmann[17]modified Pissis's procedure and used the term 'endocrown' to describe a CAD/CAM all ceramic crown which was macromechanically anchored to the internal portion of the pulp chamber and adhesively cemented to the remaining tooth structure, thereby improving micromechanical retention.
These techniques offer full occlusal coverage and take advantage of the pulp chamber to increase the available adhesive surface[18,19].

Endocrowns are another alternative method of restoration, better suited to teeth with short clinical crowns or curved or short root canals, which make post construction challenging $[1,20]$. Endocrowns have recently been suggested as a replacement for traditional metal posts and cores. This type of restoration helps preserve pulp canals and healthy coronal tooth structures. Decreasing the number of clinical procedures needed for one tooth also decreases the stress which accumulates at the interfaces of the different materials, thus decreasingthe likelihood of root fracture[3,21].

A finite element analysis showed that teeth restored with endocrowns are potentially more resistant to failure than those restored with fibre posts[22]. However, Weibull analysis suggested that the likelihood of individual failure of dentin and luting cement was reduced more with endocrowns than with traditional crowns. Other clinical studies have also confirmed the functional longevity of endocrowns[18].

A systematic review conducted in 2016 of three clinical trials [23] found that the success rate of the endocrowns was reported to be between 94 per cent and 100 per cent. Moreover, according to in vitro studies[24,25], there are no statistically significant differences between endocrowns and conventional treatments, but endocrown restorations do have higher fracture strength values than conventional restorations in anterior and posterior areas.

Recent advances in digital technology and computer-aided imaging, designing and manufacturing system (CAI, CAD and CAM, respectively) have expanded existing opportunities for improving the delivery of restorative dentistry. A number of different materials have been developed for CAD/CAM procedures, including ceramics, composites and alloys. These advances have allowed for the 
improvement of the final aesthetic results of restorations and patient satisfaction[1,20].

The type of material used may also affect the performance of endocrowns. According to the literature, glass ceramics reinforced with either leucite or high-strength lithium disilicate enhance flexibility and fracture resistance to $400 \mathrm{MPa}$. This is therefore the best option for fabricating endocrowns, as it is able to withstand occlusal force during mastication[1,26].Hybrid CAD/CAM materials such as resin ceramic and polymer-infiltrated ceramic[9] have physical and mechanical properties similar to those of natural teeth.CERASMART is a flexible nano-ceramic CAD/CAM block with high-density ultrafine glass particles 71 wt. per cent filled nanocomposite. This material combines high-strength $230 \mathrm{Mpa}$, unique aesthetics with an acceptable level of marginal adaptation, and a modulus of elasticity $(12,8 \mathrm{GPa})$ similar to that of dentin[27].

Previous studieshave shown that resin nanoceramic endocrowns have significantly higher fracture resistance and more favourable fracture mode than lithium disilicate ceramics[28-30]. Studies have also shown thatendocrowns with different preparation designs showed a clinical acceptable range of marginal and internal fit $(\leq 150 \mu \mathrm{m})[31,32]$.However, it is marginal adaptation that is one of the most important factors for the longevity of aesthetic crowns[1]. In this regard, Dalloul and Nassar [33] found that the marginal fit of endocrowns was also better than that of conventional crowns.Five-year clinical observations revealed that 87.1 percent of endocrowns in posterior teeth functioned well without fracturing or debonding[34]. Ceramic endocrowns are thus recommended for anterior teeth restoration.

It was determined to be worthwhile to evaluate CERASMART and IPS e.max press anterior endocrowns in terms of gross fracture, marginal integrity and patient satisfaction. The null hypothesis for this study is there is no significant difference between IPS e.max press endocrowns and CERASMART endocrowns in terms of gross fracture, patient satisfaction or marginal integrity.

\section{MATERIAL AND METHODS}

The materials used in the study are described below in Table I.

Table I - The brand names, materials, manufacturers and lot numbers used in this study

\begin{tabular}{|c|c|c|}
\hline Brand Name & Material Description & Manufacturer \\
\hline IPS e.max Press & $\begin{array}{l}\text { Lithium disilicate glass- } \\
\text {-ceramic (LS2) ingots for } \\
\text { the press technique }\end{array}$ & $\begin{array}{l}\text { Ivoclar Vivadent AG } \\
\text { Schaan, Liechtenstein }\end{array}$ \\
\hline CERASMART & $\begin{array}{l}\text { A resin nano-ceramic } \\
\text { material }\end{array}$ & $\begin{array}{l}\text { GC dental products, } \\
\text { Europe }\end{array}$ \\
\hline Porcelain Etchant & $\begin{array}{l}\text { Buffered Hydrofluoric Acid } \\
\text { Gel, composed of (50-75 } \\
\text { per centpoly-acryl-ami- } \\
\text { do-methylpropane sul- } \\
\text { fonic acid and 10-30 per } \\
\text { centhydrofluoric acid) }\end{array}$ & $\begin{array}{l}\text { Schaumburg, Bisco, } \\
\text { United States }\end{array}$ \\
\hline Porcelain Primer & $\begin{array}{l}\text { A single component } \\
\text { pre-hydrolysed no-mix } \\
\text { silane primer }\end{array}$ & $\begin{array}{l}\text { Schaumburg, Bisco, } \\
\text { United States }\end{array}$ \\
\hline BisCem & $\begin{array}{l}\text { A dual-cured self-adhesi- } \\
\text { ve resin cement requiring } \\
\text { no etching, priming or } \\
\text { bonding of the prepared } \\
\text { surface }\end{array}$ & $\begin{array}{l}\text { Schaumburg, Bisco, } \\
\text { United States }\end{array}$ \\
\hline $\begin{array}{l}\text { Build-ItFR fibrereinforced } \\
\text { core material }\end{array}$ & A dual-cured, auto-mixed & $\begin{array}{c}\text { Pentron Clinical Technolo- } \\
\text { gies LLC, Wallingford, CT, } \\
\text { United States }\end{array}$ \\
\hline
\end{tabular}

\section{Ethical considerations and approval}

This study was approved by the Research Ethics Committee of the Faculty of Dentistry of Cairo University, Cairo, Egypt (approval no. 1082016). Written informed consent regarding treatment sequence and publishing of their images and results was obtained from all participants.

\section{Registration}

This trial was registered at the ClinicalTrials. gov registry under registration number NCT03298152 on 12 October, 2017.

\section{Study design}

This study was a double-blind randomised controlled clinical trial with a 1:1 allocation ratio. 


\section{Participants}

All participants were recruited from the outpatient clinic of Cairo University'sDepartment of Fixed Prosthodontics in the Faculty of Dentistry. Potential participants were selected in person according to the patient's need for an aesthetic endocrown restoration for upper tooth in aesthetic zone (central incisor, lateral and canine) and invited to take part in the study.A total of 24 participants agreed to join the study from July to September 2018. The study was completed in January 2020. A full medical and dental history was obtained from each participant and the treatment plan was explained. Each participant then signedan informed consent form before the clinical work was conducted.

\section{Eligibility}

The inclusion criteria were as follows: 1 ) The participants rangedin age from 20 to 60 years, and had to be able to read and sign the informed consent document; 2) the patients had to be willing to return for follow-up examinations and evaluation; 3) the patients could not be diagnosed with another medical condition or controlled systemic disease; 4) no active periodontal disease could be present; andfinally 5) any patients with upper anterior teeth indicated for endodontic treatment must have at least $2-3 \mathrm{~mm}$ of tooth structure above the cement-enamel junction.

The following exclusion criteria were used: 1) Patients diagnosed with psychiatric problems or expressing unrealistic expectations; 2) patients with missing teeth opposing the area intended for restoration; and 3) patients with parafunctional habits (clenching/bruxism).

\section{Sample size}

A total of 24 endocrowns (12 in each group) was sufficient, with 80 per cent power and at 5 per cent significance. The sample size was calculated using PS: Power and Sample Size Calculation Software (version 3.1.2).

\section{Randomisation}

Randomisation was carried out using computerised sequence generation (https:// www.randomizer.org/) at Cairo University's Centre of Evidence-Based Dentistry. The participants were divided into two groups (A and $B$ ) according to ceramic material used either IPS e max or CERASMART. Each participant received a sealed opaque envelope with their randomisation number.

\section{Allocation concealments}

The number representing each member in each group was written on a large white paper sheet using an indelible pen. The sheet was folded eight times and sealed inside an opaque envelope so that the contentscould not be seen with the naked eye.

\section{Implementation}

The candidate under supervision was responsible for providing allocation generation and dividing patients into two groups. The group lists concealed in the envelopes were then placed in a secure location until the date that the first procedure was performed.

\section{Blinding}

The study was double-blinded (both the patients and the statistics). The trial participants and outcome assessors were blinded throughout the series of procedures because the dentist practitioner was responsible for all clinical procedures.

\section{Intervention}

Two endocrown materials (IPS e.max press and CERASMARTceramics) were selected for this study. All treatment procedures were performed by the same clinician. Scaling and polishing were performed for each patient to remove any calculus and stainingbefore shade selection in order to remove any dental plaque, as this could affect the accurate shadeselection. The tooth colour was recorded visually using a Vita Easyshade V digital spectrophotometer (VITA, Zahnfabrik, Germany). For each patient, two putty indices were obtained using condensation silicon impression material,either 
directly from the patient's mouth or indirectly from a corrected cast.Corrected casts were obtained for cases with badly broken-down teeth.

Endodontic treatment was done using the $\mathrm{Ni}$-Ti rotary system anda lateral condensation technique, and access cavities were blocked using a flowable composite (Filtek Z350, 3MESPE Dental products, St. Paul, MN, United States).At least 3 days were allowed to elapse before starting preparation for both groups.

\section{Endocrown preparation}

The flowable composite was removed from the canal orifice withoutfurther drilling inside the canal. To eliminate undercuts, the pulp chamber was prepared with a $10^{\circ}$ coronal divergence using tapered round diamond stone, with an oval shape and a depth of 4-5 $\mathrm{mm}$ from the cavo-surface margin; this was checked with periodontal probe. The internal line angles were rounded and smoothened using finishing stones.

The preparation was performed with smooth, round contours and line-angles, deep chamfer finish lines of $1 \mathrm{~mm}$ in diameter with round internal angles, and incisal reduction of $2 \mathrm{~mm}[20,35]$ (Figure 1-2). The shade of the prepared abutment tooth was recorded visually using the IPS Natural Die Material shade guide (IvoclarVivadent) in order to fabricate a die that mimicked the oral situation to achieve the optimum desired final aesthetic results.

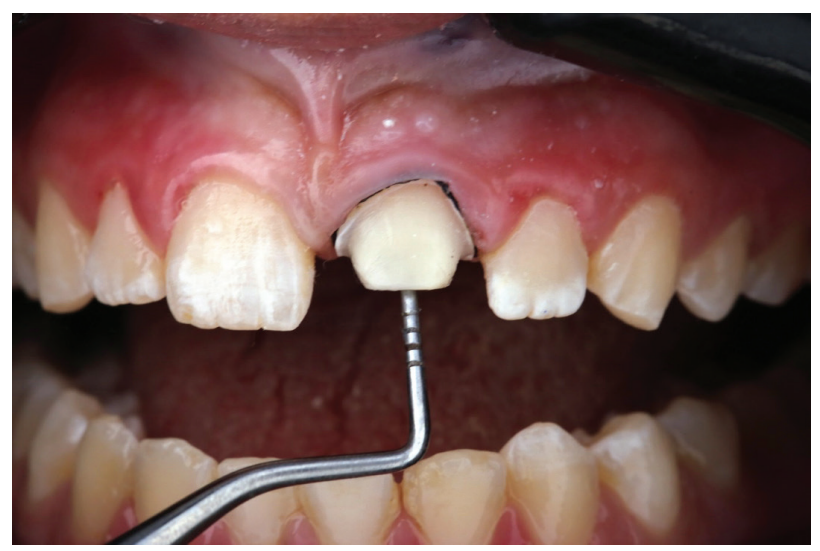

Figure 1 - Pulp chamber preparation depth checking by periodontal probe.

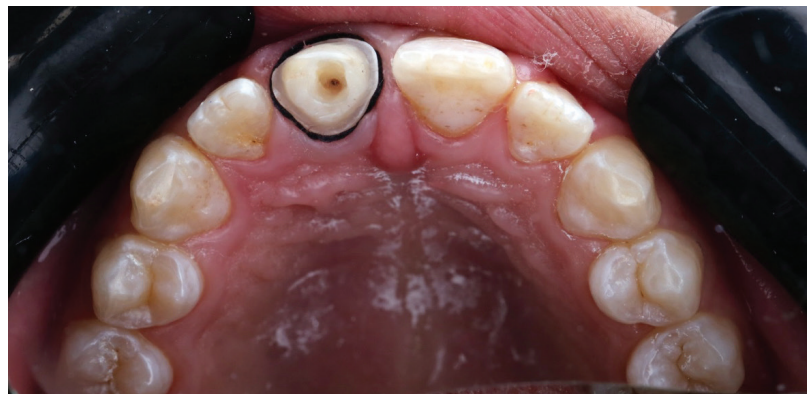

Figure 2 - Endocrown preparation occlusal view.

Vinyl polysiloxane elastomeric impressions (Elite HD+, Zhermack SpA - Via Bovazecchino, 100 - 45021 Badia Polesine (RO), Italy)were made, and provisional restorations (Structur 2 SC, VOCO, Germany) were cemented with non-eugenol provisional cement (RelyX Temp NE, 3MESPE, USA). The IPS e.max press endocrowns were constructed using a pressing furnace (Programat EP 3010, Ivoclar, VivadentAG,Schaan/Liechtenstein); the CERASMART endocrowns were constructed using a CAD/CAM Cerec inLab MC X5 milling machine with Cerec 15.0.0 software. The fitting surfaces of the all-ceramic crowns were treated and silanated according to the manufacturer's instructions and the abutment teeth were prepared with self-etch adhesive protocol using adhesive resin cement (BisCem, Bisco, United States) (Figures 3-6).

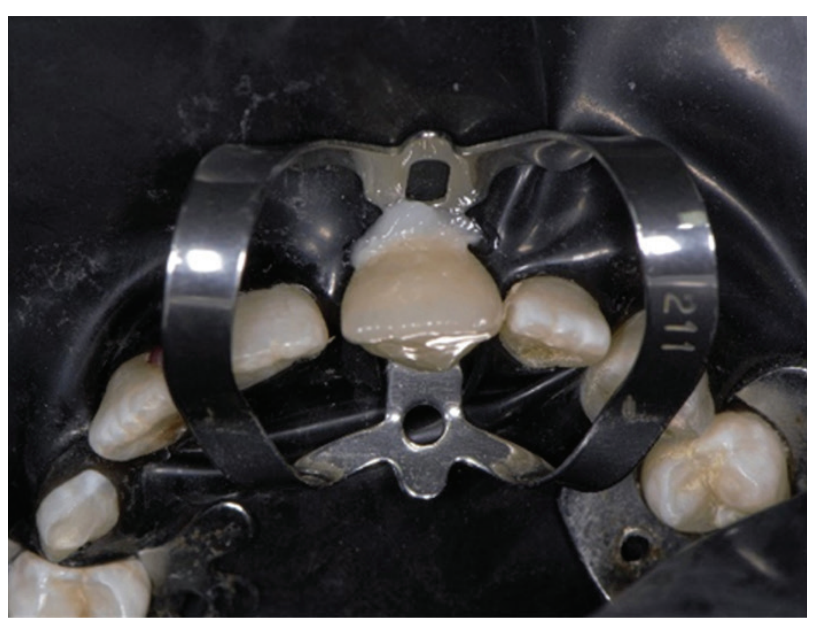

Figure 3 - Cementation of endocrown. 

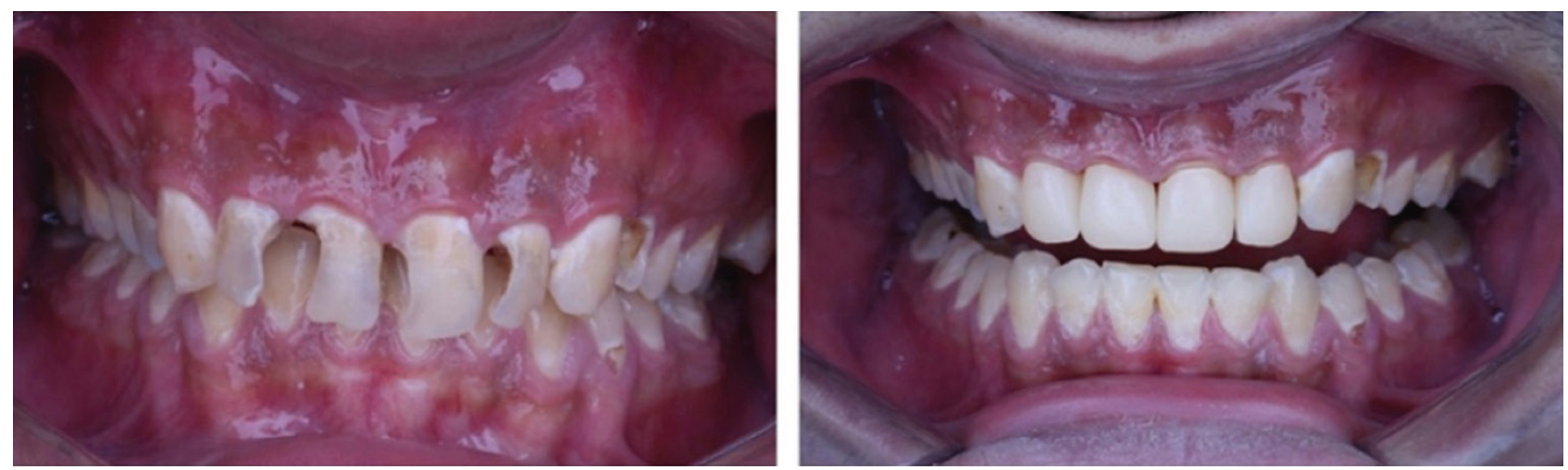

Figure 4 - Pre and post-operative CERASMART endocrown.
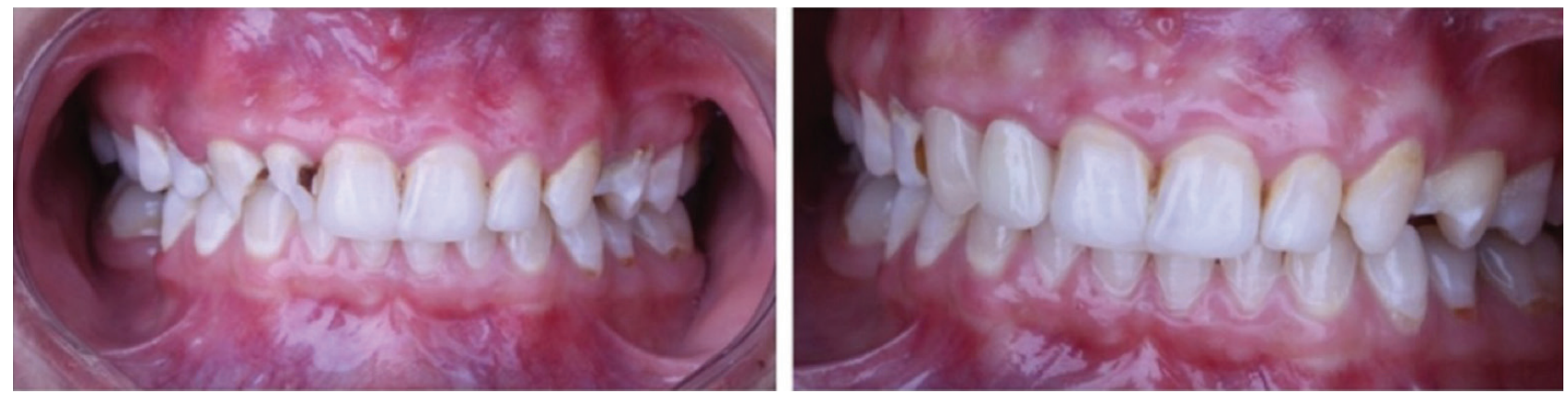

Figure 5 - Pre and post-operative emax endocrown.
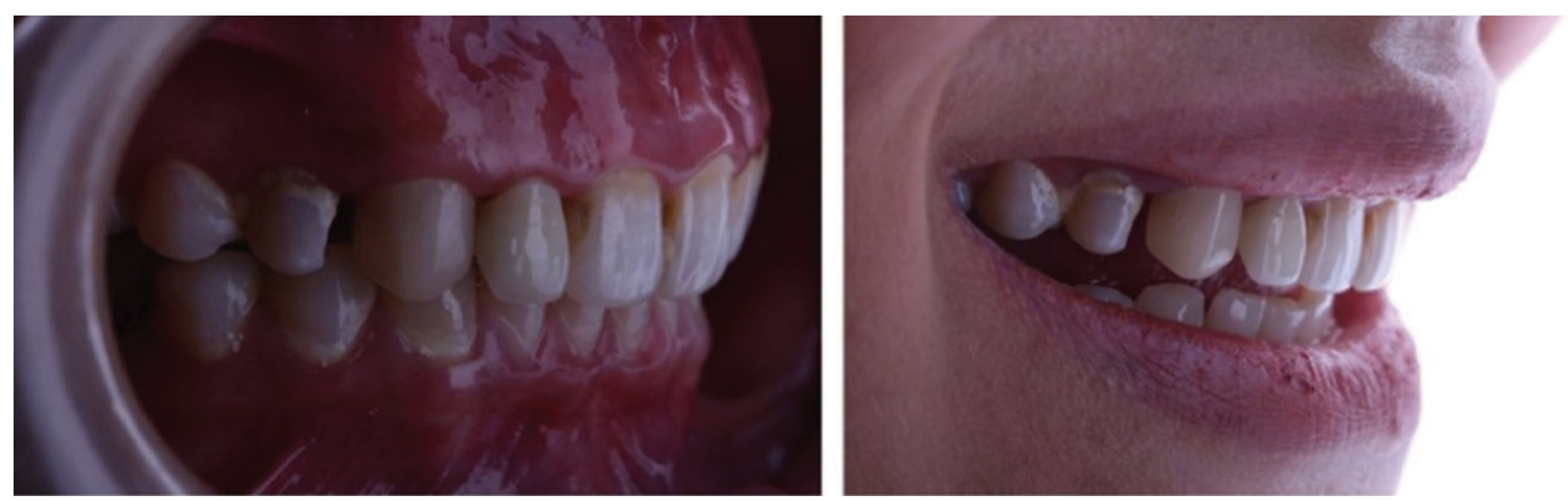

Figure 6 - Pre and post-operative emax endocrown.

\section{Clinical evaluation}

The different outcomes for all patients were measured following bonding as a baseline; the patients were then contacted via phone and SMS messages were sent to remind them of each follow-up appointment every 3 months.
All patients were followed up at 3, 6, 9 and 12 months. During each follow-up examination, the evaluator performed a direct clinical evaluation using modified United States Public Health Service (USPHS) criteria for margin integrity and gross fracture. Patients' satisfaction and potential postoperative discomfort was also evaluated using the Visual Analogue Scale (VAS). 


\section{Primary and secondary outcomes}

For primary outcome 'Gross Fracture', two groups were assessed using the modified USPHS criteria. Alpha signified 'Excellent'; Bravo signified 'Acceptable' and Charlie signified 'Unacceptable'. While Secondary outcome 'patient satisfaction and marginal integrity'the two groups were assessed For patient satisfaction using the VAS and the following scale: $1=$ yes; $2=$ no; $3=$ sometimes; and $4=$ donot know. Marginal integrity was assessed using the modified USPHS criteria.

\section{Statistical analysis}

The qualitative variables in the two groupswere compared using the $\mathrm{X}^{2}$ or Fisher's Exact test. Friedman's test was used to study the changes over time within each group. A KaplanMeier survival curve was constructed to calculate the mean survival estimates of the two groups. The significance level was set at $\mathrm{P} \leq 0.05$. The necessary statistical analyses were performed using SPSS version 23.0 (IBM, Armonk, NY, United States).

\section{RESULTS}

Gross Fracture: The results of the comparison between the two groups are presented in Table II. After 3 months; all restorations in the two groups showed (Alpha) score. While after 6, 9 as well as 12 monthsthere were significant differences between the two groups $(P=1.000$, effect size $=0.209)$; $(\mathrm{P}=1.000$, effect size $=0,128)$ and $(\mathrm{P}=0.387$, effect size $=0.333$ ), respectively.With regard to the changes over time within Group B, there was a statistically significant change in fracture scores during the study period $(\mathrm{P}=0.016$, effect size $=0.288$ ). There was an increase in prevalence of Bravo and Charlie scores after 6 months and from 6 to 9 months. There was no change in all scores from 9 to 12 months.
In Group A, there was a statistically significant change in fracture scores during the study period $(P=0.027$, effect size $=0.255)$. At 6 months the prevalence of Bravo scores had increased; at 9 months the prevalence of both Bravo and Charlie scores had increased; and at 12 months the prevalence of Charlie scores had increased further, although that of Bravo scores decreased during this period.

Table II - Descriptive statistics and the results of Fisher's exact test comparingthe fracture scores of Groups 1 and 2

\begin{tabular}{|c|c|c|c|c|c|c|c|}
\hline \multirow[t]{2}{*}{ Time } & & \multicolumn{2}{|c|}{$\begin{array}{l}\text { CERASMART } \\
(n=12)\end{array}$} & \multicolumn{2}{|c|}{$\begin{array}{c}\text { IPS e.max press } \\
(n=12)\end{array}$} & \multirow[t]{2}{*}{$P$} & \multirow[t]{2}{*}{$\begin{array}{l}\text { Effect } \\
\text { Size (v) }\end{array}$} \\
\hline & & $\mathbf{N}$ & $\%$ & $\mathbf{N}$ & $\%$ & & \\
\hline \multirow[t]{2}{*}{3 months } & Alpha & 12 & 100 & 12 & 100 & \multicolumn{2}{|c|}{ Not computed } \\
\hline & Alpha & 10 & 83.3 & 11 & 91.7 & \multirow{3}{*}{1.000} & \multirow{3}{*}{0.209} \\
\hline \multirow[t]{2}{*}{6 months } & Bravo & 1 & 8.3 & 1 & 8.3 & & \\
\hline & Charlie & 1 & 8.3 & 0 & 0 & & \\
\hline \multirow{3}{*}{9 months } & Alpha & 8 & 66.7 & 9 & 75 & \multirow{3}{*}{1.000} & \multirow{3}{*}{0.128} \\
\hline & Bravo & 2 & 16.7 & 2 & 16.7 & & \\
\hline & Charlie & 2 & 16.7 & 1 & 8.3 & & \\
\hline \multirow{3}{*}{12 months } & Alpha & 8 & 66.7 & 8 & 66.7 & \multirow{3}{*}{0.387} & \multirow{3}{*}{0.333} \\
\hline & Bravo & 2 & 16.7 & 0 & 0 & & \\
\hline & Charlie & 2 & 16.7 & 4 & 33.3 & & \\
\hline
\end{tabular}

\section{Marginal integrity}

The results of the comparison between the two groups are presented in Table III. After 3 months; all restorations in the two groups received an Alpha score. After 6, 9 and 12 months there was no statistically significant difference between the two groups $(\mathrm{P}=1.000$, effect size $=0.209 ; \mathrm{P}=1.000$, effect size $=0.236$; and $\mathrm{P}=0.387$, effect size $=0.394$, respectively). With regard to the changes over time in each group, there were no statistically significant changes in marginal integrity scores during the study period $(\mathrm{P}=0.112$, effect size $=0.200 ; \mathrm{P}=0.392$, effect size $=0.100$ ). 
Table III - Descriptive statistics and results of Friedman's test comparingthe fracture scores at different follow-up periods for each group

\begin{tabular}{|c|c|c|c|c|c|}
\hline \multirow[t]{2}{*}{ Time } & & \multicolumn{2}{|c|}{$\begin{array}{l}\text { CERASMART } \\
(n=12)\end{array}$} & \multicolumn{2}{|c|}{$\begin{array}{c}\text { IPS e.max press } \\
(n=12)\end{array}$} \\
\hline & & N & $\%$ & $\mathbf{N}$ & $\%$ \\
\hline 3 months & Alpha & 12 & 100 & 12 & 100 \\
\hline \multirow{3}{*}{6 months } & Alpha & 10 & 83,3 & 11 & 91,7 \\
\hline & Bravo & 1 & 8,3 & 1 & 8,3 \\
\hline & Charlie & 1 & 8,3 & 0 & 0 \\
\hline \multirow{3}{*}{9 months } & Alpha & 8 & 66,7 & 9 & 75 \\
\hline & Bravo & 2 & 16,7 & 2 & 16,7 \\
\hline & Charlie & 2 & 16,7 & 1 & 8,3 \\
\hline \multirow{5}{*}{12 months } & Alpha & 8 & 66,7 & 8 & 66,7 \\
\hline & Bravo & 2 & 16,7 & 0 & 0 \\
\hline & Charlie & 2 & 16,7 & 4 & 33,3 \\
\hline & $P$ & $0,016^{\star}$ & & $0,027^{\star}$ & \\
\hline & $\begin{array}{l}\text { Effect size } \\
\text { (w) }\end{array}$ & 0,288 & & 0,255 & \\
\hline
\end{tabular}

\section{Patient satisfaction}

Results of the comparison between the two groups are presented in Figure 7. At 3 months all patients in both groups reported being satisfied. At 6 months, 91.7 per cent of the patients in Group B were satisfied and 8.3 per cent were dissatisfied, while in Group A 91.7 per cent were satisfied and 8.3 per cent were dissatisfied. There was no statistically significant difference between the two groups $(\mathrm{P}=1.000$, effect size $=0.000$ ). After 9 months, 66.7 per cent of patients in Group B were satisfied and 33.3 per cent were dissatisfied. In Group A, 75 per cent of patients were satisfied and 25 per cent were dissatisfied. There was no statistically significant difference between the two groups $(\mathrm{P}=1.000$, effect size $=0.092$ ). After 12 months, 66.7 per cent of patients in Group B were satisfied and 33.3 per cent were dissatisfied. In Group A, 66.7 per cent of patients were satisfied and 33.3 per cent were dissatisfied. There was no statistically significant difference between the two groups $(P=1.000$, effect size $=0.000)$.

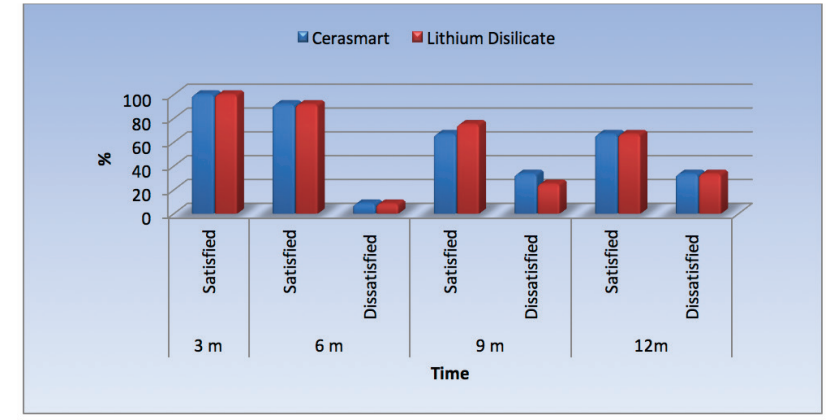

Figure 7 - Bar chart representing patient satisfaction scores in Cerasmart and IPS emax press groups.

Group Areported statistically significantly higher satisfaction than Group B. In Group A there was no statistically significant change in patient satisfaction throughout the study period $(P=0.058$, effect size $=0.208)$. In Group B there was a statistically significant change in patient satisfaction during the study period $(\mathrm{P}=0.017$, effect size $=0.283$ ). The percentage of satisfied patients decreased from 3-6 months and from 6-9 months. From 9-12 months, there was no change in the percentage of satisfied patients.

\section{DISCUSSION}

This study was a randomised, doubleblinded clinical trial.Randomisation was carried out using computerised sequence generation to eliminate the risk of selection bias inchoosing which patients were included.

The use of lithium disilicate restorations is documented in the literature as a successful method. Lithium-disilicate-based ceramics are considered among the best restorative materials for endocrowns because of their adhesive properties and their promotion of micromechanical interlocking with resin cement[35-37].

IPS e.max press is the most preferred option for manufacturing the highest-quality e.max restorations due to the lost wax process used in its manufacture and its ability to reproduce superior anatomic details. With regard to strength, both e.max processes offer some of the strongest restorations available. However, 
e.max press is 11 per cent stronger than e.max CAD. E.max has high fracture toughness (2-3 $\mathrm{MPa}$ ), high flexural strength (360-440 $\mathrm{MPa})$ and high thermal shock resistance due to its low thermal expansion;furthermore, its lithium disilicate crystals minimise the propagation of microcracks.These qualities, combined with its high aesthetic properties and bonding availability, make it the gold standard of all glass ceramic restorations[38]. It provides more precise margin integrity, less chipping and a much smoother margin line with little or no post-processing work; it also reducessintering shrinkage during ceramic firing, which further improves the marginal adaptation. The marginal fit for heat pressing ceramics was reported to range from 44-63 $\mu \mathrm{m}$ [39].Azar and Eckert [40] reported that heat-pressed lithium disilicate offers better internal fit and mechanical performance than CAD-CAM pre-crystallised blocks.

The unique composition of CERASMART gives the material a modulus of elasticity similar to that of dentin (18 $\pm 2 \mathrm{GPa}$ ) with $220-240$ MPa flexural strength.This hybrid ceramic also exhibits high flexural strength and low flexural modulus, making it less brittle and more flexible and allowing it to absorb high stress loads $[27,41,42]$.

Surface treatment of the intaglio surface of the endocrowns was done using 5 per centhydrofluoric (HF) acid for approximately 20 seconds.This treatment increases surface area, micromechanical retention and the cleanness of the surface [43]. It was followed by a coating of silane to increase the wettability of the resin cement and to interact chemically with both the resin matrix and the hydroxylated porcelain, yielding a greater resistance to water attack at the bonding interface[44,45].

All currently available in vitro studies of CERASMART have found HF acid etching in combination with silane to be a superior pre-treatment[46]. Applying HF acid partially dissolves the glass phase and provides undercuts in the micrometre scale for better micromechanical interlocking with composite cement.

Marginal fit was examined, as it seemed to be one of the most important technical factors for the long-term success of any restoration. Poor marginal fit can lead to cement dissolution, marginal discoloration, plaque retention and secondary caries[40]. Furthermore, variations in the adaptation of a restoration could lead to stress concentration, which in turn can reduce the strength of the restoration and lead to fracturing [47].The marginal adaptation of restorations is usually assessed using either invasive techniques such as cross-sectioning and impression replicas or non-invasive techniques such as indirectviewing with a dental probe.

Previous studies[48,49] have reported that CAD-CAM ceramic restorations produce an inferior marginal fit compared to pressed restorations.

USPHS guidelines were used to document patients' outcomes. Modified USPHS criteria are usually preferred in clinical trials because they enable the assessment of multiple parameters and provide reliable information regarding the overall long-term success of a restoration[50]. The USPHS criteria method can be used to investigate a tooth using visual inspection as well as tactile inspection using an explorer[51].

Patient satisfaction was also recorded as an outcome in this study, as several authors have reported discrepancies between the treatment needs perceived by patients and those assessed by dental professionals [52].

Gross fracture is another critical factor that determines the success and longevity of a restoration. After 3, 6, 9 and 12 months, there was no statistically significant difference between IPS e.max and CERASMART endocrowns with regard to gross fracture results. This finding is clinically relevant because it indicates that CERASMART endocrowns can be used instead of IPS e.max when restoring endodontically treated teeth. 
There are several factors which may affect the performance and longevity of ceramic restorations, such as the strength and thickness of the ceramic and the compatibility of the elastic moduli of the ceramics and the tooth[1].The high Alfa ratings for gross fracture generally confirm the beneficial clinical characteristics achieved with both IPS e.max press and CERASMART materials for endocrown fabrication. These comparable results may be due to the reduction of the effect of multiple interfaces, as adhesive interface failure and debonding are reduced in endocrowns. This finding confirms that of Liedberg and Norlen [53], but contradicts those of other studies[28,54]. The good adhesive properties and high resistance to displacement of both materials is due to the fact that they are acid-etched, which provides micro-mechanical interlocking with the resin cement $[23,55]$. Moreover, the amount of remaining ferrule and the modification in the butt joint preparation with complete encircling of the tooth structure increasesthe surface area for bonding, which reduces the transmitted stress and improves resistance to force[3,23,56].

With regard tomarginal integrity results,after 3, 6, 9 and 12 months there was no statistically significant difference between IPS e.max and CERASMART endocrowns. This may be due in part to the strict and meticulous fabrication and cementation protocol followed for each material. This finding confirms that of Goujat and Abouelleil [57].

There are several factors that may affect the marginal adaptation of the restorations, including fabrication technique, preparation design, spacer thickness, the type of finish line, geometry of tooth preparation, the material used to create the crown, the fabrication technique and cementation[39]. A shallow intra-coronal cavity depth of endocrown preparation is attributed to the proper seating of the endocrown. The IPS e.max pressing technique reduces sintering shrinkage during ceramic firing, thus improving marginal adaptation, whereas CERASMART material has low hardness, which improves good machinability and reduces chipping in the restoration[58].

With regard to patient satisfaction,all patients reported being satisfied with their restorations after $3,6,9$ and 12 months and there was no statistically significant difference between the two groups. We believe these results to be reasonable as theyarea combined reflection of the best materials and bonding protocolsavailable. No post-treatment discomfort was reported[59-60].

These findings confirm the hypothesis, as there was no significant difference in the clinical performance of IPS e.max press endocrowns compared to CERASMART endocrowns.

\section{Acknowledgments}

The authors are grateful to Dr. Amina Zaki and Dr. Jylan for content contributions, Dr. Amina Zaki and Dr. Jylan for their critical review of the manuscript and the Dr. Amina Zaki and Dr. Jylan for support during the development and writing of this manuscript.

\section{Funding}

This study was partially supported by ( self funded).

\section{Conflict of interest}

The authors have no proprietary, financial, or other personal interest of any nature or kind in any product, service, and/or company that is presented in this article.

\section{Regulatory Statement}

This study was conducted in accordance with all the provisions of the local human subject's oversight committee guidelines and policies of: yes

The approval code for this study is: 171010.

\section{REFERENCES}

1. Kanat-ErtÜRk B, SaridaĞ S, KÖSeler E, HelvacioĞLu-YiĞltD, Avcu E, Yildiran-Avcu Y. Fracture strengths of endocrown restorations fabricated with different preparation depths and CAD/CAM materials. Dent Mater J. 2018;37(2):256-65. 
2. Zhou L, Wang Q. Comparison of fracture resistance between cast posts and fiber posts: ameta-analysis of literature. J Endod. 2013;39(1):11-5.

3. Elagra M. Endocrown preparation. Int J Appl Dent Sci. 2019;5(1):253-6.

4. Al shibri S, Elguindy J. Fracture resistance of endodontically treated teeth restored with lithium disilicate crowns retained with fiber posts compared to lithium disilicate and cerasmart endocrowns: in vitro study. Dent. 2017;7(12):e12. doi:10.4172/2161-1122.1000464

5. Giannini M, Maia HP, Anderson RE, Bruzi G, Carvalho A0, Magne P. Influence of no-ferrule and no-post buildup design on the fatigue resistance of endodontically treated molars restored with resin nanoceramic CAD/CAM crowns. Oper Dent. 2014;39(6):595-602.

6. Rezaei Dastjerdi M, Amirian Chaijan K, Tavanafar S. Fracture resistance of upper central incisors restored with different posts and cores. Restor Dent Endod. 2015;40(3):229-35.

7. Yousif Marghalani T, Tharwat Hamed M, Abdelmageed Awad M, Hussein Naguib G, Fouad Elragi A. Three-dimensional finite element analysis of custom-made ceramic dowel made using CAD/CAM technology. Prosthodont. 2012;21(6):440-50.

8. Schwartz RS, Jordan R. Restoration of endodontically treated teeth: the endodontist's perspective, part 1. Endodontics: Colleagues for ExcellenceAAE Spring/Summer. 2004:1-6.

9. BankoĞLu GÜNgÖRM, Turhan Bal B, Yilmaz H, Aydin C, Karakoca Neml S Fracture strength of $\mathrm{CAD} / \mathrm{CAM}$ fabricated lithium disilicate and resin nano ceramic restorations used for endodontically treated teeth. Dent Mater J. 2017;36(2):135-41.

10. Ferrari M, Vichi A, Grandini S. Efficacy of different adhesive techniques on bonding to root canal walls: an SEM investigation. Dent Mater. 2001;17(5):422-9.

11. Krejcil, Mueller E, Lutz F. Effects of Thermocycling and Occlusal Force on Adhesive Composite Crowns. J Dent Res. 1994;73(6):1228-32.

12. Hayashi M, Sugeta A, Takahashi Y, Imazato S, Ebisu S. Static and fatigue fracture resistances of pulpless teeth restored with post-cores. Dent Mater. 2008;24(9):1178-86.

13. Rocca GT, Krejci I. Crown and post-free adhesive restorations for endodontically treated posterior teeth: from direct composite to endocrowns. Eur J Esthet Dent. 2013;8(2):156-79.

14. Isidor F,Brøndum $K$, Ravnholt $G$. The influence of post length and crown ferrule length on the resistance to cyclic loading of bovine teeth with prefabricated titanium posts. Int J Prosthodont. 1999;12(1):78-82.

15. Fernandes AS, Dessai GS. Factors affecting the fracture resistance of postcore reconstructed teeth: a review. Int J Prosthodont. 2001;14(4):355-63.

16. Pissis P.Fabrication of a metal-free ceramic restoration utilizing the monobloc technique. Pract Periodontics Aesthet Dent. 1995;7(5):83-94.

17. Bindl A, Mormann WH. Clinical evaluation of adhesively placed Cerec endocrowns after 2 years-preliminary results. J Adhes Dent. 1999;1(3):255-65.

18. Biacchi GR, Mello B, Basting RT. The endocrown: an alternative Approach for restoring extensively damaged molars. J Esthet Restor Dent. 2013;25(6):38390.

19. Ghajghouj 0, Taşar-Faruk S. Evaluation of fracture resistance and microleakage of endocrowns with different intracoronal depths and restorative materials luted with various resin cements. Materials. 2019:12(16):2528.

20. El Badawy A, Abd El Aziz M, Omar E. Effect of laminate veneer designs on abfraction incidence using different loading conditions "finite element analysis". EgyptDent J. 2019;65(2):1645-52.
21. Dejak B, Młotkowski A.3D-Finite element analysis of molars restored with endocrowns and posts during masticatory simulation. Dent Mater. 2013;29(12):e309-17.

22. Dejak B, Młotkowski A. The influence of ferrule effect and length of cast and FRC posts on the stresses in anterior teeth. Dent Mater. 2013;29(9):e227-37.

23. Sedrez-Porto JA, Rosa WLdOd, da Silva AF, Münchow EA, Pereira-Cenci T Endocrown restorations: a systematic review and meta-analysis. J Dent. 2016;52:8-14.

24. Chang C-Y, Kuo J-S, Lin Y-S, Chang Y-H. Fracture resistance and failure modes of CEREC endo-crowns and conventional post and core-supported CEREC crowns. JDent Sci. 2009;4(3):110-7.

25. Lin C-L, Chang Y-H, Pai C-A. Evaluation of failure risks in ceramic restorations for endodontically treated premolar with MOD preparation. Dent Mater. 2011;27(5):431-8.

26. Tzimas K, Tsiafitsa M, Gerasimou P, Tsitrou E. Endocrown restorations for extensively damaged posterior teeth: clinical performance of three cases. Restor Dent Endod. 2018;43(4):e38.

27. Alzayer AA. Microleakage of lithium disilicate ceramic crowns and nano ceramic crowns: a comparative study [thesis]. Boston: Tufts University School of Dental Medicine; 2016

28. Platt JA, Haj-Ali RN, El-Damanhoury HM. Fracture Resistance and Microleakage of Endocrowns Utilizing Three CAD-CAM Blocks. Oper Dent. 2015;40(2):201-10

29. Lawson NC, Bansal R, Burgess JO. Wear, strength, modulus and hardness of CAD/CAM restorative materials. Dent Mater. 2016;32(11):e275-e283.

30. Taha D, Spintzyk S, Sabet A, Wahsh M, Salah T. Assessment of marginal adaptation and fracture resistance of endocrown restorations utilizing different machinable blocks subjected to thermomechanical aging. J Esthet Restor Dent. 2018;30(4):319-28.

31. Elalem IA, Ibraheem RM, Hamdy AM. Clinical evaluation of the marginal integrity, and internal fit of E-Max endocrown restorations with different marginal preparation designs: ex-vivo study. J Dent Or Health. 2019:2.

32. EI Ghoul WA, Özcan M, Ounsi H, Tohme H, Salameh Z. Effect of different CAD-CAM materials on the marginal and internal adaptation of endocrown restorations: an in vitro study. J Prosthet Dent. 2020;123(1):128-34.

33. Dalloul R, Nassar J, Al-Houri N. A comparative study of marginal fit between IPS e MAX press crown and endocrown after cementation (In vitro). Clinical Medicine and Diagnostics. 2016;6(5):122-5. doi:10.5923/j.cmd.20160605.02

34. Otto T, Mörmann W. Clinical performance of chairside CAD/CAM feldspathic ceramic posterior shoulder crowns and endocrowns up to 12 years. Int $\mathrm{J}$ Comput Dent. 2015;18(2):147-61.

35. Dejak B,Młotkowski A. Strength comparison of anterior teeth restored with ceramic endocrowns vs custom-made post and cores. J Prosthodont Res. 2018;62(2):171-6.

36. Gresnigt MMM, Cune MS, de Roos JG, Özcan M. Effect of immediate and delayed dentin sealing on the fracture strength, failure type and Weilbull characteristics of lithiumdisilicate laminate veneers. Dent Mater. 2016;32(4):e73-81.

37. Basting RT, Biacchi GR. Comparison of fracture strength of endocrowns and glass fiber post-retained conventional crowns. Oper Dent. 2012;37(2):130-6.

38. Bajraktarova-Valjakova E, Korunoska-Stevkovska V, Kapusevska B, Gigovski N, Bajraktarova-Misevska C, Grozdanov A. Contemporary dental ceramic materials, areview: chemical composition, physical and mechanical properties, indications for use. Open Access Maced J Med Sci. 2018:6(9):1742-55 
39. El-Dessouky RA, Salama MM, Shakal MA, Korsel AM. Marginal adaptation of CAD/CAM zirconia-based crown during fabrication steps. Tanta Dent J 2015;12(2):81-8.

40. Azar B, Eckert S, Kunkela J, Ingr T, Mounajjed R. The marginal fit of lithium disilicate crowns: Press vs. CAD/CAM. Braz Oral Res. 2018;32:e001

41. Awada A, Nathanson D. Mechanical properties of resin-ceramic CAD/CAM restorative materials. JProsthet Dent. 2015;114(4):587-93.

42. Bhat V, Shenoy K, Dandekeri S, Reddy H. CAD-CAM CERAMICS-A litrature review. Int J Recent Sci Res. 2016;7(3):9352-61.

43. Correr-Sobrinho L, Sinhoreti MAC, Gonçalves LS, Moraes RR, Soares CJ, Naves LZ. Surface/interface morphology and bond strength to glass ceramic etched for different periods. Oper Dent. 2010;35(4):420-7.

44. Meng XF, Yoshida K, Gu N. Chemical adhesion rather than mechanical retention enhances resin bond durability of a dental glass-ceramic with leucite crystallites. Biomed Mater. 2010;5(4):044101.

45. Kitayama S, Nikaido T, Takahashi R, Zhu L, Ikeda M, Foxton RM, et al. Effect of primer treatment on bonding of resin cements to zirconia ceramic. Dent Mater. 2010;26(5):426-32.

46. Van Meerbeek B, Baratieri LN, Vieira LCC, De Munck J, Van Ende A, Lise DP.Microtensile bond strength of composite cement to novel CAD/ CAM materials as a function of surface treatment and aging. Oper Dent. 2017:42(1):73-81.

47. Vojdani M, Safari A, Mohaghegh M, Pardis S, Mahdavi F. The effect of porcelain firing and type of finish line on the marginal fit of zirconia copings. JDent. 2015;16(2):113-20.

48. Anadioti E, Aquilino SA, Gratton DG, Holloway JA, Denry I, Thomas GW, et al. 3D and 2D marginal fit of pressed and CAD/CAM lithium disilicate crowns made from digital and conventional impressions. J Prosthodont. 2014;23(8):610-7.

49. Dolev E, Bitterman Y, Meirowitz A. Comparison of marginal fit between CAD-CAM and hot-press lithium disilicate crowns. J Prosthet Dent. 2019:121(1):124-8.
50. Ercan E, Dülgergil CT, Soyman M, Dalli M, Yildirim I. A field-trial of two restorative materials used with atraumatic restorative treatment in rural Turkey:24-month results. J Appl Oral Sci. 2009;17(4):307-14.

51. Heffernan MJ, Aquilino SA, Diaz-Arnold AM, Haselton DR, Stanford CM, Vargas MA. Relative translucency of six all-ceramic systems,part Il: core and veneer materials. JProsthet Dent. 2002;88(1):10-5.

52. Locker D, Slade G. Association between clinical and subjective indicators of oral health status in an older adult population. Gerodontology. 1994;11(2):10814.

53. Liedberg B, Norlen P,Owall B. Teeth, tooth spaces, and prosthetic appliances in elderly men in Malmo, Sweden. Community Dent Oral Epidemiol. 1991;19(3):164-8.

54. Ramírez-Sebastià A, Bortolotto T, Cattani-Lorente M, Giner L, Roig M, Krejci I. Adhesive restoration of anterior endodontically treated teeth: influence of post length on fracture strength. Clin Oral Investig. 2014;18(2):545-54.

55. Pedrollo Lise D, Van Ende A, De Munck J,Umeda Suzuki TY, Cardoso Vieira LC, Van Meerbeek B. Biomechanical behavior of endodontically treated premolars using different preparation designs and CAD/CAM materials. J Dent. 2017;59:54-61.

56. Einhorn M, DuVall N, Wajdowicz M, Brewster J, Roberts H. Preparation ferrule design effect on endocrown failure resistance. JProsthodont. 2019;28(1):e237-e42.

57. Goujat A, Abouelleil H, Colon P, Jeannin C, Pradelle N, Seux D, et al Mechanical properties and internal fit of 4 CAD-CAM block materials. $\mathrm{J}$ Prosthet Dent. 2018;119(3):384-9.

58. Bindl A, Mormann WH. Marginal and internal fit of all-ceramic CAD/CAM crown-copings on chamfer preparations. J Oral Rehabil. 2005;32(6):441-7.

59. Zou Y,Bai J, Xiang J. Clinical performance of CAD/CAM-fabricated monolithic zirconia endocrowns on molars with extensive coronal loss of substance. Int J Comput Dent. 2018;21(3):225-32.

60. Samer MS, Faraz Q, Al-Dubai SAR, Vohra F, Abdullah H, Taiyeb-Ali TB, et al. Clinical outcomes and predictors of satisfaction in patients with improved lithium disilicate all-ceramic crowns. Med Princ Pract. 2017;26(5):470-9.

Norhan Naief Abd El Haliem (Corresponding address)

Lecturer Assistant, Fixed Prosthodontics, Faculty of Oral and Dental Medicine, Egyptian Russian University, Badr city, Cairo- Suez road, Postal Code 11829, Cairo, Egypt.

Email: norhan.naief@dentistry.cu.edu.eg

Date submitted: 2020 Jul 26

Accept submission: 2020 Sep 15 